\title{
V CONGRESO INTERNACIONAL SOBRE ENFERMEDADES INFECCIOSAS
}

\section{Viena (Agosto 31 - Sept. 5 - 1970)}

El BACTRIM es una asociación de sulfametoxazol y trimetoprim. El primero inhibe el ácido para-aminobenzoico que es necesario para el desarrollo de los gérmenes, ejerciendo de este modo, una acción bacteriostática. El trimetoprim es un derivado de la pirimidina e inhibe la síntesis bacteriana del ácido fólico que desempeña papel fundamental en el metabolismo bacteriano al bloquear la reductasa del ácido dihidrofólico. Con el BACTRIM, disponemos ahora de un producto de acción tanto bacteriostática como bactericida, ya que bloquea dos procesos de síntesis de gran importancia para el metabolismo bacteriano.

Diversos estudios han demostrado que la asociación de sulfametoxazol y trimetoprim tiene un efecto antibacteriano mucho más marcado que cada uno de los componentes por separado. La asociación produce una potencialización del efecto antibacteriano.

En lo que respecta a la actividad antibacteriana, el BACTRIM posee un amplio espectro de acción contra las bacterias gram-positivo y gramnegativo que se encuentran principalmente en el hombre.

Los componentes del BACTRIM (sulfametoxazol y trimetoprim) se hallan en dicho producto en una relación de 5:1. Un comprimido contíene 400 mg. de sulfametoxazol y $80 \mathrm{mg}$. de trimetoprim.

Nosotros tratamos con BACTRIM en nuestra clínica un total de 75 pacientes con afecciones cutáneas. 66 de ellos eran mujeres y 9 hombres, y la edad oscilaba entre 14 y 86 años. Sus dermatosis se debían, en unos casos, a una infección bacteriana primitiva y en otros, a una infección bacteriana secundaria. Hemos tratado 36 casos de úlcera de la pierna, 9 de tromboflebitis - a veces complicada con absceso- 8 de dermatosis varicosas de estasis, 8 de acné vulgar, conglobata o pustulosa, y 14 de otras dermatosis como furunculosis, impétigo contagioso, rosácea pustulosa, zona, eritema exudativo multiforme, fisura anal $\mathrm{y}$ absceso.

Antes de comenzar el tratamiento, determinamos, mediante cultivo a partir de frotis, los gérmenes presentes en las dermatosis y su sensibilidad al BACTRIM. Aislamos el estafilococo piógeno dorado, estafilococo blanco, Pseudomonas aeruginosa, colibacilo, enterococos, Proteus, estreptococos alfa-hemolíticos, Corynebacterium, Klebsiella, y levaduras en tres casos. Algunas de las cepas de Pseudomonas aeruginosa y enterococos 
fueron resistentes al BACTRIM. Casi en todos los casos, ya no se les podía identificar en los cultivos testigos después del tratamiento con BACTRIM. Aunque durante el tratamiento hemos podido cultivar cepas bactericmas que seguían siendo sensibles al BACTRIM, pudiera tratarse de nuevos gérmenes que luego desaparecieron también.

\section{CUADRO 1}

\section{Indicaciones $\mathrm{y}$ resultados terapéuticos en 75 pacientes tratados con BACTRIM}

\begin{tabular}{|c|c|c|c|c|c|c|c|}
\hline Diagnóstico & $\mathrm{N}^{0}$ & de & Casos & Curación & Regresión & $\begin{array}{l}\text { ado del tra } \\
\text { Statu quo }\end{array}$ & $\begin{array}{l}\text { iento } \\
\text { Efectos } \\
\text { secundarios }\end{array}$ \\
\hline Ulcera de la pierna & & 36 & & 5 & 28 & 3 & $2 \times$ diarrea \\
\hline $\begin{array}{l}\text { Tromboflebitis } \\
\text { Dermatosis varicosa }\end{array}$ & & 9 & & 6 & 3 & 一 & $1 \times$ diarrea \\
\hline $\begin{array}{l}\text { de estasis } \\
\text { Acné (vulgar, conglo- }\end{array}$ & & 8 & & 5 & 2 & 1 & 一 \\
\hline $\begin{array}{l}\text { bata, pustulosa) } \\
\text { Otras dermatosis }\end{array}$ & & 8 & & - & 7 & 1 & 一 \\
\hline infecciosas & & 14 & & 10 & 3 & 1 & 1 x náuseas \\
\hline TOTAL & & 75 & & 26 & 43 & 6 & \\
\hline
\end{tabular}

Para tratar las afecciones cutáneas -junto con la aplicación de medicamentos adecuados de uso externo-, hemos administrado un comprimido de BACTRIM dos veces al día o 2 comprimidos de BACTRIM dos veces al día durante 3 a 28 días. La importancia de las dosis y la duración del tratamiento estaban en relación con la gravedad de la lesión y en algunos casos, también con la tolerancia del paciente. La dosis total osciló entre 8 y 88 comprimidos por individuo, con un promedio aproximado de 42 comprimidos. La duración del tratamiento fue, por lo general, de 12 a 15 días. En algunos casos en que el sujeto no reaccionó suficientemente a la medicación, se aumentó la dosis inicial de un comprimido 2 veces al día a 2 comprimidos dos veces al día, lo que mejoró apreciablemente el resultado terapéutico. Durante la administración de BACTRIM, las mencionadas afecciones mostraron franco regreso (Cuadro 1). Por lo general, se inhibió por completo el desarrollo de las bacterias en la piel, lo que abrevió considerablemente la fase de exudación. Las zonas cutáneas erosionadas o ulcerosas se limpiaron y no tardaron en presentar un buen comienzo de granulación y epitelización. En un total de 75 casos, el BACTRIM produjo completa curación en 26, mejoría manifiesta del cuadro clínico en 43 y sólo en 6 no tuvo éxito alguno.

Además de su buen efecto terapéutico, el BACTRIM es muy bien tolerado. Muchas sulfonamidas produjeron en diversos casos fenómenos de intolerancia, como trastornos gastrointestinales, cefaleas, vómitos, vértigo, trastornos hepatorrenales y reacciones alérgicas cutáneas.

Para valorar objetivamente estos efectos secundarios, efectuamos exámenes clínicos y hematológicos así como del quimismo sanguíneo antes 
de comenzar el tratamiento. Se excluyó de este a los pacientes que, según los datos de la anamnesis y los exámenes, eran propensos a dichos trastornos. En el curso del tratamiento y después de él, controlamos regularmente el estado general, fórmula hemática, orina y funciones hepática y rencl.

Nunca observamos modificaciones patológicas de los valores de laboratorio. El BACTRIM fue muy bien tolerado. Sólo 4 sujetos presentaron signos de reacciones secundarias, enteritis leve en 3 y náuseas en 1 ; en los otros 71 no observamos ninguna manifestación secundaria.

En vista de estos resultados, puede afirmarse que el BACTRIM constituye un valioso enriquecimiento de nuestro arsenal terapéutico para las dermatosis bacterianas. 